\title{
THE IMPACT OF SEASONALITY ON TOURIST'S ARRIVAL IN BANGLADESH BY USING SANCOVA MODEL
}

\author{
Sayed Mohibul HOSSEN* \\ Universiti Sains Malaysia, School of Mathematical Sciences, 11800 USM Penang, Malaysia. Mawlana Bashani \\ Science and Technology University, Department of Statistics, Tangail 1902, Bangladesh, e-mail: m300cht@gmail.com
}

Mohd Tahir ISMAIL

Universiti Sains Malaysia, School of Mathematical Sciences, 11800 USM Penang, Malaysia, e-mail: m.tahir@usm.my

Mosab I. TABASH

Al Ain University, College of Business, Al Ain, United Arab Emirates, e-mail: mosab.tabash@aau.ac.ae

Suhaib ANAGREH

Higher Collges of Technology, Abu Dhabi, United Arab Emirates, e-mail: sanagreh@ hct.ac.ae

\begin{abstract}
Citation: Hossen, S.M., Ismail, M.T., Tabash, M.I., \& Anagreh, S. (2021). THE IMPACT OF SEASONALITY ON TOURIST'S ARRIVAL IN BANGLADESH BY USING SANCOVA MODEL. GeoJournal of Tourism and Geosites, 38(4), 1118-1124. https://doi.org/10.30892/gtg.38417-751
\end{abstract}

\begin{abstract}
In this study, we aim to highlight the impact of climate change as well as seasonality on tourist's arrival in Bangladesh. The SANCOVA modeling framework modified by the ANCOVA model is used to examine the impact of climate change on tourists' arrivals. The results show seasonality has a $91 \%$ effect on tourist's arrival in Bangladesh. The maximum and minimum variation of climatic variables on tourists' arrival in Bangladesh is rainfall and humidity, respectively. The winter and summer seasons have similar and more impact on tourist's arrival in Bangladesh. Our findings indicate that the tourism industry of Bangladesh is more vulnerable to seasonal variation than the overall economy. The present study has significant implications for both policymakers and tourisms destination alike to plan for tourism in Bangladesh.
\end{abstract}

Key words: Seasonal effect, Tourists' arrival, GDP, SANCOVA model, Bangladesh

\section{INTRODUCTION}

Tourism is a great tool for poverty alleviation by creating new jobs at different levels and engaging local people in them, the tourism industry supports reducing poverty to a great extent. The outcome in the recent analysis, researchers have found an association between environmental sustainability and economic growth which encourages policymakers to give attention to it (Sun et al., 2019). Climatic variables and the changes in them also have a significant effect on the overall economy of a country in diverse ways (Siddig et al., 2020). Climate factors like temperature, moisture and rainfall are linked to social entertainment in open spaces for your convenience (Dillimono, 2015). Higher temperatures and weather pressures have a good link with entertainment in the spring for outdoor comfort (Keller et al., 2005). Higher temperatures, however, lead to more negative attitudes which overcome comfort in summer. Seasonal fluctuations affect the link between climate factors and attitude variability (Beecher et al., 2016).

Due to the seasonal environment, tourists may discover the availability and quality of several open-air activities. Various sorts of tourist goods, such winter sports and water sports, are devoted to the seasonal tourism, including natural sites and beach tourism (Liu et al., 2017). In the field of economics, it has been proposed that the impact of climatic changes has significant effects on GDP (Wu, 2016). By improving the necessity for tourism prospects, it is a great opportunity for destination countries to lift their economic growth by fascinating tourists through the creation of innovative tourism segments and proper utilization of natural sights (Dogru et al., 2019). It is well conventional that gross domestic product (GDP) decline smooth increasing but fluctuates around a growth trend (Sheldon, 2017). At present, there are more than 170 developing countries with rich natural resources, but the poor economic and technological foundations catalyze inefficient investment especially in infrastructure construction (Zhang at el., 2019).

In the region, Bangladesh is with less income and income from the tourist sector (Pennington and Thomsen, 2010). Now, amongst the ten nations that depend the most on home tourism for their Travel \& Tourism industry, Bangladesh is included as rising economies (WTTC-2019). Ahmed and Study (2016) also carried out the Cox's Bazar, Bangladesh, study on sustainable tourist development. The current state of the tourism industry in Bangladesh was observed by Ara Parveen (2013). The current status of the tourist sector and the contribution to GDP was presented to Roy et al., (2020). Hossen et al., (2021) talked about tourism might deliver a wide range of economic, social and environmental advantages, especially in

\footnotetext{
* Corresponding author
} 
rural and underdeveloped regions, that has indicated a favorable trend of income and income in the country. The main cause for international tourist arrivals in Bangladesh has supposedly been the study carried out by Islam and Islam (2004). However, no study can empirically determine the climate variable as well as the seasonality on Bangladesh's tourist arrival. In this study we attempt to explore empirically the influence of the climate variable on the arrival of tourists and on Bangladesh's national economy that fills the investigation divide. Figure 1 shows the framework of the study.

\section{LITERATURE REVIEW}

Climate circumstances have an overall influence, which indicates that modest warming levels should be disputed (Henseler and Schumacher, 2019). Climate change is a possible major danger to economic growth and poverty with a high level of adaptive ability exposure (Elshennawy et al., 2016). Public adaptation to climate change promotes directly to government budgets for investment (Bachner et al., 2019). Climate change effects on the tourism industry that knocked the developing countries which may be expected merging of per capita of the national economy (Taconet, 2020). Climate factors are crucial and also have an essential link to the tourist actors in choosing the place and plans to travel in various seasons (Zhang and Kulendran, 2017).

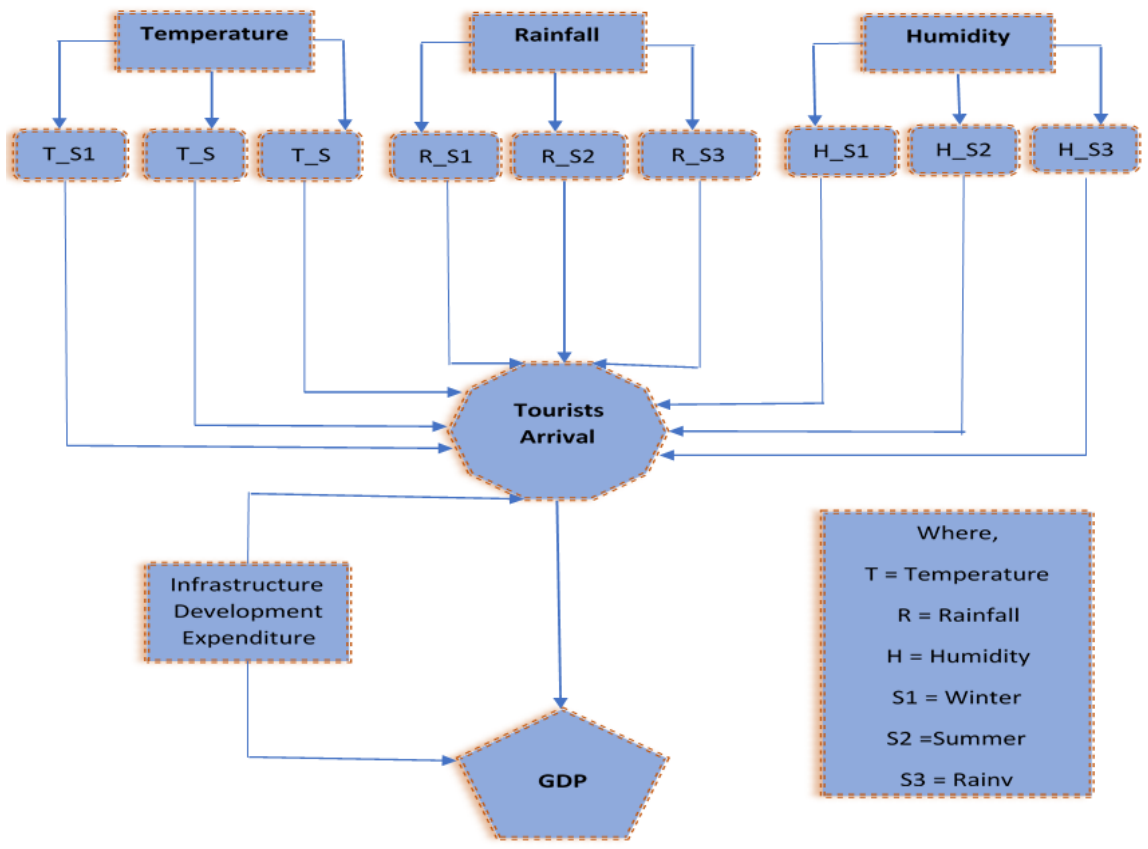

Figure 1. The Framework of the study

Seasonal fluctuation is therefore a key factor in tourism demand. Politicians therefore recognized seasonality as an important issue and tackled it at the strategy, decision, marketing and operational levels ( $\mathrm{Li}$ et al., 2018). Several scholars claimed that there is a positive association between the level of economic growth and environmental concern, along with ecological modernization (Knight, 2016). Briefly, processes of modernization increased the reflexivity throughout the socioeconomic scheme (Jorgenson et al., 2018). It is notable that if investment ensures its profits, normally increases the amount of investment (Komendantova et al., 2019). Otherwise, any investment for improving environmental development causes penalties that reduced profits would defend stockholders to finance (Sroufe and Remani, 2018). The development must be conceived and conducted such that sufficient resources are available for future generations to satisfy their demands (Lior, 2017).

The Bangladeshi tourist sector is the potential segment to make a major contribution to Bangladesh's economy. Proper growth of this sector may generate an enormous quantity of foreign cash that will help the national economy to improve. This offers persons directly or indirectly active in this field sufficient work opportunities. This sector will contribute to family incomes and government incomes in the neighborhood. It also contributes to reducing the economic gaps among the country's affluent and poor. People from established nations differ from developing nations in lifestyles, backgrounds and income, such as Bangladesh. It may be possible for Bangladeshi people to compare their way of life with the inhabitants of other affluent nations. Bangladesh may be introduced through the tourist sector in the rest of the globe. It may also be helpful to establish a better image for outside nations by managing sustainable tourism operations appropriately. If the sector is well handled and individuals from diverse areas of the country and worldwide sources may be fascinated by Bangladesh's attractions, it will develop the country with a good will (Kalam, 2018).

\section{MATERIALS AND METHODS}

\section{Data Collection}

Bangladesh's climate divides the year into three distinct seasons: the wet or monsoon season, which lasts from May to October; the colder season, which lasts from October to February; and the dry season, which lasts from March to May. The chilly season is the most comfortable time to visit the nation. During the monsoon season, heavy rains are common, making travel in certain locations difficult. We composed secondary climatic data from the Bangladesh Meteorological Department (BMD) and Bangladesh Agricultural Research Council (BARC). No. of tourists' arrival, Expenditure for tourism development, and Income from tourism data have been collected from Bangladesh Parjatan Corporation (BPC), Ministry of Civil Aviation and Tourism, Bangladesh Bureau of Statistics (BBS), different reports, published articles, websites, Daily newspapers, etc. These data will help to examine the relationship between changes in the climate and tourism business. Major objectives to conduct this research are as follows:

1. To focus and compare our proposed model, how it can perform better in the application of seasonal variation.

2. To examine the seasonal effect on tourist's arrival as well as on the GDP of Bangladesh.

3. To evaluate the impacts of the tourism industry on the national economy of Bangladesh. 


\section{Classical linear regression model (CLRM)}

A fundamental economic premise is that with the increase of demand the income in question increases, and with the decrease of demand the income decreases. This is a direct link between the demand for the goods and the owner's revenue. Taking into account the economic hypothesis in the current investigation we are trying to build a model with an income model for the coming to Bangladesh of visitors. The considered income model is (author),

$$
Y_{\text {it }}=\beta_{1}+\beta_{2} X_{t}+u_{\text {it }} \ldots \text { (i) }
$$

Where, $Y_{\text {it }}=$ Annual income from tourism; $X_{\mathrm{t}}=$ Total no. of tourists' arrival -th year in Bangladesh $u_{i t}=$ disturbance terms; $\beta_{1}$ and $\beta_{2}$ are known as the regression coefficient.

They are also called intercept and slope coefficients, respectively. EQ. (i) can be written as follows:

$$
\begin{aligned}
Y_{\text {it }} & =\hat{\beta}_{1}+\hat{\beta}_{2} X_{t}+\hat{u}_{i t} \ldots \text { (ii) } \\
& =\hat{Y}_{i t}+\hat{u}_{i t} \ldots \text { (iii) }
\end{aligned}
$$

Where $\hat{Y}_{\text {it }}$ is the estimated value of $Y_{\text {it }}$. Now we can write from eq. (iii)

$$
\hat{u}_{i}=Y_{i t}-\hat{Y}_{i t}=Y_{i t}-\beta_{1}-\hat{\beta}_{2} X_{t} \ldots \text { (iv) } \sum \hat{u}_{i}^{2}=\sum\left(Y_{i t}-\hat{Y}_{i t}\right)^{2}=\Sigma\left(Y_{i t}-\hat{\beta}_{1}-\hat{\beta}_{2} X_{t}\right)^{2} \ldots \text { (v) }
$$

If $\sum \hat{u}_{t}^{2}$ is as small, we can estimate the coefficient $\beta_{1}$ and $\beta_{2}$ as follows.

$$
\sum Y_{\mathrm{it}}=n \hat{\beta}_{1}+\hat{\beta}_{2} \sum X_{\mathrm{t}} \ldots \text { (vi) } \sum Y_{\mathrm{it}} X_{\mathrm{t}}=\hat{\beta}_{1} \sum X_{\mathrm{t}}+\hat{\beta}_{2} \sum X_{\mathrm{t}}^{2} \ldots
$$

Solving the normal equations simultaneously, we obtain

$$
\hat{\beta}_{2}=\sum \frac{n \sum X_{\mathrm{t}} Y_{\mathrm{it}}-\sum X_{\mathrm{t}} \Sigma Y_{\mathrm{it}}}{n \sum X_{\mathrm{t}}^{2}-\left(\sum X_{\mathrm{t}}\right)^{2}}=\frac{\left(X_{\mathrm{t}}-\hat{X}\right)\left(Y_{\mathrm{it}}-\hat{Y}\right)}{\sum\left(X_{\mathrm{t}}-\hat{X}\right)^{2}}=\frac{\sum x_{\mathrm{i}} y_{\mathrm{i}}}{\sum x_{\mathrm{i}}^{2}}
$$

Where, $\bar{X}, \bar{Y}$ are the sample means of $\mathrm{X}$ and Y. we define

$$
x_{i}=\left(X_{\mathrm{t}}-\bar{X}\right) \text { and } y_{i}=\left(Y_{i t}-\bar{Y}\right) \text { and } \bar{\beta}_{1}=\frac{\sum x_{\mathrm{L}}^{2} \sum Y-\sum x_{L} Y}{n \sum x_{\mathrm{L}}^{2}-\left(\sum x_{\mathrm{L}}\right)^{2}}=\bar{Y}-\bar{\beta}_{2} \bar{X} \ldots
$$

\section{The SANCOVA model}

The covariance analysis (ANCOVA) model is named every Regression Model including both quantitative and qualitative variables in common. These models of ANCOVA are an addition to ANOVA. This methodology gives a quantitative regress control variable statistically checking effect (Gujrati, 1995). We presented a modified ANCOVA model named the seasonal analysis of covariance (SANCOVA) to find out how the tourist and the turistic income of different seasons will effect (Hossen et al.,2021). One of this model's important benefits over another model of regression is that we may assess not only the connection of the independent variable and its partial effect, but also compare its qualitative effects. At initially, we split climate information into three seasons, namely winter/cool, summer/dry and rainy/wet. There are three climate factors, including temperature, precipitation and moisture, each season. In this study, only six factors are taken into account in realizing the constraints of data availability. In such cases, the coming of visitors is considered as the dependent (endogenous) variable for determining the relationship between the entrance of visitors and the seasonal effect. Total tourist development expenditure and three seasonal factors are deemed independent (exogenous). In this situation, income is treated as dependent (endogenous) variable as well as independent (exogenous) factors for seasonal and tourist arrival effects on GDP. The whole tourism development expenses, three seasons and the arrival of visitors are taken into account. Depending on the nature of the phenomena and the purposes of the study being considered, this model must incorporate a number of variables. Total tourists and total development expenses are quantitative factors in this study, along with seasons when climate factors are treated as qualitative characteristics. We investigate the dummy variable for three times to estimate the seasonal impact on visitors' arrivals and incomes. So in this study we take into account the seasonal covariance analysis (SANCOVA) model. Our dummy variable regression model is therefore as follows (author).

$$
\begin{aligned}
& \text { Tourists } \text { it }=\beta_{0}+\left(\beta_{1} s_{1 H}+\beta_{2} S_{1 R}+\beta_{3} S_{1 T}\right) \sum_{i=1}^{n} \text { Wet }(j u n e-\text { October })+\left(\beta_{4} S_{2 H}+\beta_{5} S_{2 R}\right. \\
& \left.+\beta_{6} S_{2 T}\right) \sum_{i=1}^{n} \operatorname{Cool}(\text { November }- \text { February })+\left(\beta_{7} S_{3 H}+\beta_{g} S_{3 R}+\beta_{9} S_{3 T}\right) \sum_{i=1}^{n} \text { Dry }(\text { March }- \text { May }) \\
& +\beta_{10} \text { Expenditure }_{t}+u_{\frac{i t}{n}} \quad \ldots(x) \\
& \text { Income } \left._{\text {it }}=\beta_{0}+\left(\beta_{1} S_{1 H}+\beta_{2} S_{1 R}+\beta_{3} S_{1 T}\right) \sum_{i=1}^{\text {it }} \text { Wet (june - October }\right)+\left(\beta_{4} S_{2 H}+\beta_{5} S_{2 R}\right. \\
& \left.+\beta_{6} S_{2 T}\right) \sum_{i=1}^{n} \operatorname{Cool}(\text { November }- \text { February })+\left(\beta_{7} S_{a H}+\beta_{g} S_{a R}+\beta_{g} S_{a T}\right) \sum_{i=1}^{n} \text { Dry }(\text { March }- \text { May }) \\
& +\beta_{11} \text { Tourists }_{t} u_{\text {it }} \quad \ldots(X I)
\end{aligned}
$$

Where, $\beta_{0}=$ Intercept term,

$$
\begin{aligned}
& S_{1 H}=\text { Humidity in cool/winter season, } \\
& S_{1 R}=\text { Rainfall in cool/winter season, } \\
& S_{1 T}=\text { Temperature in cool/winter season, } \\
& S_{2 H}=\text { Humidity in dry/summer season, }
\end{aligned}
$$

$S_{2 R}=$ Rainfall in dry/summer season

$S_{2 \pi}=$ Temperature in dry/summer season

$S_{3 H}=$ Humidity in the wet season

$S_{2 R}=$ Rainfall in the wet season

$S_{a T}=$ Temperature in the wet season 


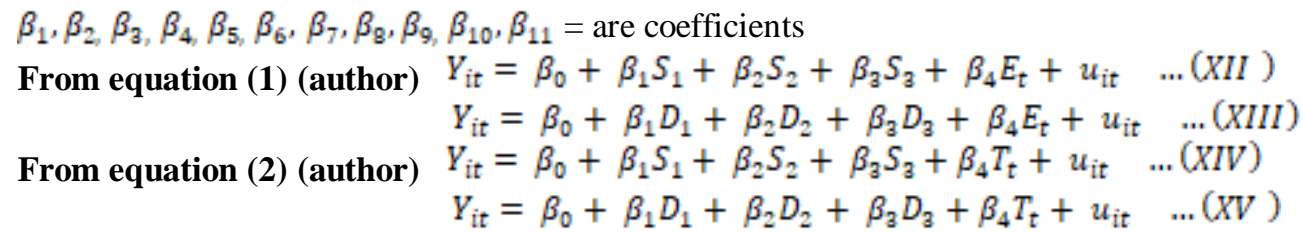

Where, $Y_{\text {it }}=$ Total income from tourists

$\beta_{0}=$ Intercept term,

$S_{1}=$ Tourists arrival in winter/cool season,

$S_{3}=$ Tourists arrival in wet/rainy season

$S_{2}=$ Tourists arrival in summer/dry season,

$E_{\mathrm{t}}=$ Expenditure for tourism development in the th year

$T_{t}=$ Total number of tourists' arrival at the t-h year

$$
\begin{aligned}
& \left.D_{1}=\begin{array}{cc}
1, \text { when winter season } \\
0,
\end{array}\right\} \\
& \left.D_{2}=\begin{array}{ll}
1_{s} \text { when dry/summer season } \\
0, & \text { othewise }
\end{array}\right\} \\
& \left.D_{a}=\begin{array}{lr}
1_{s} \text { when wet season } \\
0,
\end{array}\right\} \\
& u_{\text {it }}=\text { disturbance terms } \\
& \beta_{1,} \beta_{2}, \beta_{3,} \beta_{4} \text { and } \beta_{5}=\text { are coefficients }
\end{aligned}
$$

\section{Structural Equation Modeling (SEM)}

Structural equation modeling (SEM) is a sophisticated multivariate methodology used in scientific research for testing and assessing multivariate causal connections. SEMs vary from other modeling techniques in that they assess direct and indirect impacts on pre-assumed casual connections (Arhonditsis et al., 2006). There are two sorts of variables employed in this analysis: endogenous variables and exogenous variables. Endogenous variables are the same as dependent variables and have the same value as the independent variable. It can be difficult to quantify abstract concepts such as "climate change," "ecosystem structural composition," and "ecosystem service" in ecological study. If there are no direct measurements for these abstractions, SEM does a confirmatory factor analysis to estimate latent components.

Model specification, identification, parameter estimate, model assessment, and change are the five logical phases in structural equation modeling (Fan et al., 2016). In structural equation modeling, model specification showed the predicted connection between variables (SEM). The model's identification check determines if it is over-identified, just-identified, or under-identified. The model's coefficients can only be computed for the just-identified or over-identified models. Model evaluation computes the overall goodness of fit in order to measure model performance. Modification, also known as posthoc model modification, involves adjusting the model to improve model fit. Impose the validation procedure to increase the model's dependability and stability (Fan et al., 2016). We used the Smart PLS-SEM to analyze the data in this study because it produces more accurate findings.

\section{RESULTS AND DISCUSSION}

\section{Estimation of CLRM model}

Table 1 shows the results of the influence of seasonal effects on visitors' arrivals by CLRM. Here, the multiple coefficients of determination $\left(R^{2}\right)$ for all climatic variables Temperature, Rainfall and Humidity are $0.74,0.996$, and 0.723 , respectively. This result suggests that the climatic variable individually explained the tourist's arrival in Bangladesh by $74 \%, 99.6 \%$, and $72 \%$ respectively. More clearly, seasonality in temperature, rainfall, and humidity have $74 \%, 99.6 \%$, and $72 \%$ effect respectively on tourist's arrival in Bangladesh. This indicates that tourists in Bangladesh are more vulnerable to rainfall than temperature and humidity. This result also tells us temperature has a negative impact in winter and summer seasons on tourist arrival whereas it has a positive impact in the wet season. On the other hand, seasonality in rainfall has a negative impact in the winter and wet seasons but has a positive effect in the summer season. For the climatic variable humidity, it has a negative effect in the wet season but a positive effect in the winter and summer seasons. This outcome suggests that the tourism industry of Bangladesh is more vulnerable to climate variables as well as seasonality. Estimating the effect of seasons and tourist's arrival on Income by CLRM, we get the results in Table 2.

Table 1. Results of Tourists arrival by CLRM model

\begin{tabular}{|l|c|c|c|c|c|c|}
\hline $\begin{array}{l}\text { Climatic } \\
\text { Variables }\end{array}$ & $\begin{array}{c}\text { Tourists } \\
\text { arrival } \\
\left(\beta_{0}\right)\end{array}$ & $\begin{array}{c}\text { Winter } \\
\text { season } \\
\left(\beta_{1}\right)\end{array}$ & $\begin{array}{c}\text { Summer } \\
\text { season } \\
\left(\beta_{2}\right)\end{array}$ & $\begin{array}{c}\text { Wet } \\
\text { season } \\
\left(\beta_{3}\right)\end{array}$ & $R$ & $R^{2}$ \\
\hline Temperature & $-6.6466 \mathrm{E} 6$ & -0.042 & -1.174 & 0.898 & 0.860 & 0.740 \\
\hline Rainfall & 229925 & -1.035 & 1.701 & -0.894 & 0.998 & 0.996 \\
\hline Humidity & 206494 & 0.466 & 1.007 & -0.380 & 0.850 & 0.723 \\
\hline
\end{tabular}

Table 2. Results of Income by CLRM model

\begin{tabular}{|l|c|c|c|c|c|c|}
\hline $\begin{array}{l}\text { Climatic } \\
\text { Variables }\end{array}$ & $\begin{array}{c}\text { Income } \\
\left(\beta_{0}\right)\end{array}$ & $\begin{array}{c}\text { Winter } \\
\text { season } \\
\left(\beta_{1}\right)\end{array}$ & $\begin{array}{c}\text { Summer } \\
\text { season } \\
\left(\beta_{2}\right)\end{array}$ & $\begin{array}{c}\text { Wet } \\
\text { season } \\
\left(\beta_{2}\right)\end{array}$ & $R$ & $R^{2}$ \\
\hline Temperature & 37339 & -0.422 & -0.935 & 0.130 & 0.888 & 0.789 \\
\hline Rainfall & 7702 & -1.533 & 1.384 & -0.508 & 0.991 & 0.995 \\
\hline Humidity & 8998 & 1.127 & 0.747 & -0.393 & 0.948 & 0.898 \\
\hline
\end{tabular}

Here, the multiple coefficients of determination $\left(R^{2}\right)$ for all climatic variables Temperature, Rainfall and Humidity are $0.789,0.995$, and 0.898 , respectively. This result suggests that the climatic variable individually explained the Income from tourist's arrival in Bangladesh by $78.9 \%, 99.5 \%$, and $89.8 \%$ respectively. More clearly, seasonality in temperature, rainfall, and humidity have $78.9 \%, 99.5 \%$, and $89.8 \%$ effect respectively on Income from tourist's arrival in Bangladesh. This indicates that the income from tourist's arrival in Bangladesh is more vulnerable to rainfall than temperature and humidity.

\section{Estimation of SANCOVA model}

Table 3 shows the result of estimating the influence of seasonal effects on visitor arrivals. For the whole reference class here, the multiple determination coefficients i.e. $\left(R^{2}\right)$ are 0.91 . This result implies that $91 \%$ of the total variance was 
explained by the independent variable. The influence of seasonality on tourist arrivals in Bangladesh is $91 \%$. This study also indicates that the arrival of visitors will grow by average 75 persons per season if tourism development spending grows in Taka (Taka is the currency of Bangaldesh, 1 Taka equals to 0.012 USD) each year.

Table 3. Results of Tourists arrival by SANCOVA model

\begin{tabular}{|l|c|c|c|c|c|c|c|}
\hline $\begin{array}{l}\text { Reference } \\
\text { category }\end{array}$ & $\beta_{0}$ & $\beta_{1}$ & $\beta_{2}$ & $\beta_{3}$ & $\beta_{4}$ & $R$ & $R^{2}$ \\
\hline $\begin{array}{l}\text { Winter } \\
\text { season }\end{array}$ & $\begin{array}{c}- \\
22149\end{array}$ & & 0.000 & 0.637 & 0.075 & 0.95 & 0.91 \\
\hline $\begin{array}{l}\text { Summer } \\
\text { season }\end{array}$ & $\begin{array}{c}- \\
22149\end{array}$ & 0.000 & & 0.637 & 0.075 & 0.95 & 0.91 \\
\hline Wet season & 48605 & -.637 & -.637 & & 0.075 & 0.95 & 0.91 \\
\hline
\end{tabular}

Table 4. Results of Income by SANCOVA model

\begin{tabular}{|l|c|c|c|c|c|c|c|c|}
\hline $\begin{array}{c}\text { Reference } \\
\text { category }\end{array}$ & $\beta_{0}$ & $\beta_{1}$ & $\beta_{2}$ & $\beta_{3}$ & $\beta_{4}$ & $R$ & $R^{2}$ & Seasonal \\
\hline $\begin{array}{l}\text { Winter } \\
\text { season }\end{array}$ & 5414 & & 0.000 & 0.104 & 0.527 & 0.67 & 0.45 & 0.181 \\
\hline $\begin{array}{l}\text { Summer } \\
\text { season }\end{array}$ & 5414 & 0.000 & & 0.104 & 0.527 & 0.67 & 0.45 & 0.181 \\
\hline Wet season & 5564 & -0.104 & -0.104 & & 0.527 & 0.67 & 0.45 & 0.181 \\
\hline
\end{tabular}

\section{Considering Winter season as the reference category}

The mean value of the category of reference is $\beta_{0}$, known as the intercept term, i.e. winter season. The intercept value $\beta_{0}$ is the mean value, i.e. the winter season, in the reference group. In the current research, then, the intercept value is around 48605 visitors, representing the average arrival of visitors over the winter season. $\beta_{2}$ shows us that the average arrivals of visitors to summer is equivalent to the average arrival of 48065 visitors for winter season, the reference category. $\beta_{3}$ provides the result that the mean tourist's arrival in Wet/Rainy season is higher about 0.6370 thousand tourists than the mean tourists' arrival of about 48065 tourists for the reference category, Winter season.

. $\beta_{3}$ results in a mean tourist arrival of roughly $0,6370,000$ tourists in the wet/rainy season, greater than the mean tourist arrival of roughly 48,065 visitors for the winter season reference category.

\section{Estimation of SANCOVA model}

Table 4 shows the effect of seasons and tourist's arrival on Income per capita in Bangaldesh. The coefficient of determination value for all reference categories $\left(R^{2}\right)$ is 0.45 , indicating that the independent variable explained $45 \%$ of the overall variation. The above finding also suggests that if tourist arrivals increase by a thousand per season, income will rise by an average of 0.527 million Taka every season. It also tells us that if development spending increases by lakh Taka every year, income would rise by 0.181 million Taka per season.

\section{Considering Winter season as the reference category}

The mean value of the reference category is represented by $\beta_{0}$, which is known as the intercept term, i.e., the winter season. The intercept value $\beta_{0}$ represents the reference category's mean value, i.e. the Winter season. As a result, the intercept value of the regression model in the current analysis is around 5414 lakh Taka, which reflects the mean income from visitor arrivals throughout the Winter season. $\beta_{2}$ tells us the mean income from tourists' arrival in the summer season is equal to the mean tourists' arrival of about 5414 lakh Taka for the reference category, Winter season.

$\beta_{3}$ provides the result

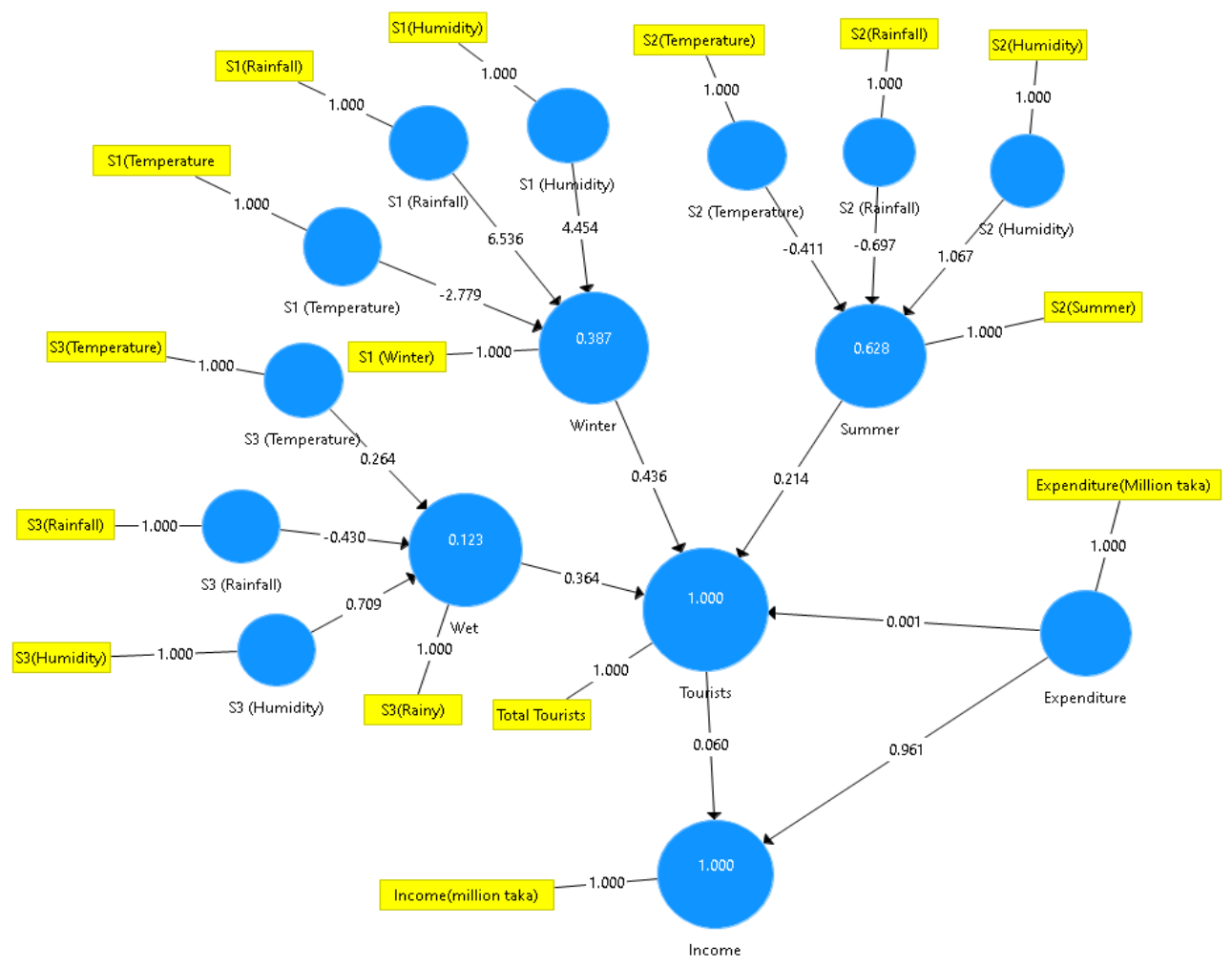

Figure 2. Standardized results of SEM calculations

that the mean income from tourist's arrival in Wet/ Rainy season is higher about 0.104 lakh taka than the mean income from tourists' arrival of about 5414 lakh Taka for the reference category, Winter season.

\section{Structural Model Assessment}

Figure-2 shows the structural model assessment. Using the bootstrapping process implemented to figure out the t-values 
and R square. This figure tells us the winter, summer, and wet seasons have a partial effect on tourist's arrival is 0.436 , 0.214 , and 0.364 , respectively. This indicates that the winter, summer, and wet seasons explained tourist's arrival by $43 \%$, $21 \%$, and $36 \%$ of the total variation, respectively.

\section{Discriminant validity: Fornell-Larcker criterion}

To evaluate the discriminate validity for assessing the model Fornell-Larcker criterion (1981) was applied. Moreover, the square root of all Seasons (in bold) corresponding to tourists' arrival describes the highest within a range of 0.953-0.997. This result suggests that humidity in winter, the temperature in summer, and heavy rainfall in the rainy season harm tourist's arrival. Thus, it is well comprehensible that discriminant validity is sustained between seasons and the tourist's arrival for this estimated model of the study as shown in Table 5.

Table 5. Values of correlations between seasons and square roots of the tourists and income in the main diagonal in the SEM

\begin{tabular}{|c|c|c|c|c|c|c|c|c|c|c|c|c|c|c|c|}
\hline \multirow{2}{*}{\begin{tabular}{|l} 
S1(Humidity) \\
\end{tabular}} & S1_H & S1_R & S1_T & S2_H & S2_R & S2_T & S3_H & S3_R & S3_T & Summer & Wet & Winter & Tourists & Expenditure & Income \\
\hline & & & & & & & & & & & & & & & \\
\hline S1 (Rainfall) & -0.911 & & & & & & & & & & & & & & \\
\hline S1(Temperature) & -0.516 & -0.816 & & & & & & & & & & & & & \\
\hline \begin{tabular}{|l|} 
S2 Humidity) \\
\end{tabular} & -0.349 & 0.610 & 0.688 & & & & & & & & & & & & \\
\hline S2 (Rainfall) & -0.305 & 0.643 & 0.855 & 0.926 & & & & & & & & & & & \\
\hline S2(Temperature) & -0.546 & 0.247 & -0.124 & -0.583 & -0.525 & & & & & & & & & & \\
\hline S3 Humidity) & 0.403 & -0.020 & 0.559 & 0.239 & 0.513 & -0.535 & & & & & & & & & \\
\hline S3 (Rainfall) & 0.514 & -0.156 & 0.384 & -0.236 & -0.399 & -0.680 & 0.920 & & & & & & & & \\
\hline S3(Temperature) & -0.902 & 0.677 & 0.165 & -0.135 & 0.034 & 0.674 & -0.701 & -0.830 & & & & & & & \\
\hline Summer & -0.149 & -0.034 & 0.001 & 0.662 & 0.750 & -0.507 & -0.045 & -0.044 & -0.036 & & & & & & \\
\hline Wet & -0.118 & 0.314 & 0.391 & 0.816 & 0.753 & -0.773 & 0.129 & 0.003 & 0.124 & -0.905 & & & & & \\
\hline Winter & -0.026 & -0.211 & 0.250 & 0.721 & 0.071 & -0.659 & 0.025 & -0.104 & 0.044 & -0.935 & 0.986 & & & & \\
\hline Tourists & -0.039 & 0.198 & 0.251 & 0.754 & 0.167 & -0.564 & 0.049 & -0.053 & 0.099 & -0.953 & -0.989 & 0.997 & & & \\
\hline Expenditure & 0.742 & -0.597 & -0.301 & 0.220 & 0.678 & -0.790 & 0.260 & 0.306 & -0.603 & -0.769 & 0.554 & 0.608 & -0.633 & & \\
\hline Income & 0.708 & -0.564 & -0.284 & \begin{tabular}{|l|}
0.259 \\
\end{tabular} & \begin{tabular}{|l|}
0.196 \\
\end{tabular} & -0.795 & 0.240 & 0.284 & -0.569 & -0.801 & 0.590 & 0.643 & 0.668 & 0.999 & \\
\hline
\end{tabular}

The CLRM contains information on the individual influence of the meteorological variable, as well as its seasonality, on tourist arrivals and the national economy. We may use structural equation modeling to determine the partial influence of a climatic

$\begin{array}{cc}\text { Model } & R^{2} \\ \text { Linear } & 82 \% \\ \text { SANCOVA } & 91 \%\end{array}$

Variable on tourist arrivals and the national economy, but we cannot compare variables within variables. For the quantitative variable, we may use the two models mentioned above. However, with SANCOVA, we may combine quantitative and qualitative factors. As a result of the previous three models, we can conclude that the SANCOVA model is the best for the current analysis since it allows us to evaluate not only the coefficient of determination but also compare the seasonality's influence on tourist arrivals as well as the national economy. Again, the coefficient of determination obtained by this model is bigger than the coefficients obtained by the other two models.

In the present globalization, the tourism industry is a powerful appliance for economic growth for any developing country as well as in developed countries. Including Bangladesh, this growth is faster in developing countries rather than the developed countries. Our average growth rate of GDP is around 6\%, which is highly dependent on the export of workforce, Ready Made Garments, agricultural sector, shipbuilding, and pharmaceuticals, etc. The unemployment rate is higher than the expected level. Consequently, the low wage rate at masquerading employment and unemployment is increasing. As a result, many people are illegally crossing the border for uncertainty in the hope of a better future. By taking an immediate initiative of some projects and policies, the government can improve the employment rate and can stop illegal migration, through this, which may bring social, cultural, and economic benefits. The government should give equal emphasis on its policy and will increase investment all over the country for the development of the tourist spots.

\section{CONCLUSION}

In the analysis, we found that seasonality has a $91 \%$ effect on tourist's arrival in Bangladesh. It indicates findings of the present study have significant repercussions for both policymakers and tourisms destination alike. The above result also recommends that, if tourist's arrival will increase thousand per season then income will increase on the average by 0.527 million Taka per season. This result also suggests that if the expenditure on tourism development increases lakh Taka per year, then the arrival of tourists will increase on average by 75 people per season. It also tells us if development expenditure will increase lakh Taka per year then income will increase 0.181 million Taka every season.

Finally, we have concluded that the tourist's arrival in Bangladesh is increasing day by day. The weather and climatic condition of our country are good for tourism. As the no. of tourist's arrival is increasing so the income from tourism is also increasing which contributes to our GDP. From this analysis, it is clear that the tourism demand is responsive to climate change as well as seasonality. Since tourist's arrival are depends on seasonality then we can also decide that the GDP of our country is positively related to seasonality. Economic theory suggests that the coefficient of the demand for supply equation is positive. That is, as expected demand rises, the corresponding supply rises. This indicates that there is a direct relationship between expected climate changes as well as the seasonality of our country and the tourist's arrival. The maximum and minimum variation of climatic variables on tourists' arrival in Bangladesh is rainfall and humidity, respectively. The winter and summer seasons have similar and more impact on tourist's arrival in 
Bangladesh. Our findings also indicate that the tourism industry of Bangladesh is more vulnerable to seasonal variation than the overall economy. So, we can conclude in a decision that our proposed modified ANCOVA modeling named SANCOVA is better than any other regression model in the case of evaluating the seasonal effect on the national economy. Therefore, tourism stakeholders can apply this model in exponents for policymaking, recommend adaptation and justification, and be inventors of any subsequent policy arrangements. Furthermore, in developing different tourism industries, the finding has a significant role that may add to economic recovery for overall economic growth.

\section{REFERENCES}

Ahmed, S., \& Study, C. (2016). Sustainable Tourism Development in Bangladesh A Case Study of Cox's Bazar, Bangladesh Bachelo 's. Thesis Centria University of Applied Sciences Degree Programme in Tourism.

Ara Parveen, J. (2013). Current Status of Tourism Industry In Bangladesh: An Empirical Evaluation. Scientific Research Journal (SCIRJ), 1(1), 41. www.scirj.org

Arhonditsis, G. B., Stow, C. A., Steinberg, L. J., Kenney, M. A., Lathrop, R. C., McBride, S. J., \& Reckhow, K. H. (2006). Exploring ecological patterns with structural equation modeling and Bayesian analysis. Ecological Modelling, 192(3-4), 385-409. https://doi.org/10.1016/j.ecolmodel.2005.07.028

Bachner, G., Bednar-Friedl, B., \& Knittel, N. (2019). How does climate change adaptation affect public budgets? Development of an assessment framework and a demonstration for Austria. Mitigation and Adaptation Strategies for Global Change, 24(7), 1325-1341. https://doi.org/10.1007/s11027-019-9842-3

Beecher, M.E., Eggett, D., Erekson, D., Rees, L.B., Bingham, J., Klundt, J., \& Boardman, R.D. (2016). Sunshine on my shoulders: Weather, pollution, and emotional distress. Journal of Affective Disorders, 205, 234-238. https://doi.org/10.1016/j.jad.2016.07.021

Dillimono, H.D. (2015). Travel, tourism, climate change, and behavioral change: travelers' perspectives from a developing country, Nigeria. Journal of Sustainable Tourism, 23(3), 437-454. https://doi.org/10.1080/09669582.2014.957212

Dogru, T., Marchio, E.A., Bulut, U., \& Suess, C. (2019). Climate change: Vulnerability and resilience of tourism and the entire economy. Tourism Management, 72 (December 2018), 292-305. https://doi.org/10.1016/j.tourman.2018.12.010

Elshennawy, A., Robinson, S., \& Willenbockel, D. (2016). Climate change and economic growth: An intertemporal general equilibrium analysis for Egypt. Economic Modelling, 52, 681-689. https://doi.org/10.1016/j.econmod.2015.10.008

Fan, Y., Chen, J., Shirkey, G., John, R., Wu, S.R., Park, H., \& Shao, C. (2016). Applications of structural equation modeling ( SEM ) in ecological studies : an updated review. Ecological Processes. https://doi.org/10.1186/s13717-016-0063-3

Gujrati, D.N. (1995). Basic econometrics, New York: Me Graw-Hill.

Henseler, M., \& Schumacher, I. (2019). The impact of weather on economic growth and its production factors. Climatic Change, 154(34), 417-433. https://doi.org/10.1007/s10584-019-02441-6

Hossen, S.M., Ismail, M.T., \& Tabash, M.I. (2021). The Impact of Seasonality in Temperature Forecast on Tourist Arrivals in Bangladesh: an Empirical Evidence. GeoJournal of Tourism and Geosites, 34(1), 20-27. https://doi.org/10.30892/gtg.34103-614

Hossen, S.M., Ismail, M.T., Tabash, M.I., \& Abousamak, A. (2021). Accrued forecasting on tourist's arrival in Bangladesh for sustainable development. Geojournal of Tourism and Geosites, 36(2), 708-714. https://doi.org/10.30892/gtg.362spl19-701

Jorgenson, A. K., Fiske, S., Hubacek, K., Li, J., Mcgovern, T., Rick, T.,\& Zycherman, A. (2018). Social science perspectives on drivers of and responses to global climate change. WIREs Climate Change, 1-17. https://doi.org/10.1002/wcc.554

Kalam, A. (2018). Environmentally Sustainable Tourism Problem and Prospects in Bangladesh: A Study on Coastal Region at Cox's Bazar. 8(1), 18-25.

Keller, M.C., Fredrickson, B.L., Ybarra, O., Côté, S., Johnson, K., Mikels, J., \& Wager, T. (2005). A warm heart and a clear head: The contingent effects of weather on mood and cognition. Psychological Science, 16(9), 724-731. https://doi.org/10.1111/j.1467-9280.2005.01602.x

Knight, K. W. (2016). Public awareness and perception of climate change: a quantitative cross-national study. 1042(February). https://doi.org/10.1080/23251042.2015.1128055

Komendantova, N., Schinko, T., \& Patt, A. (2019). De-risking policies as a substantial determinant of climate change mitigation costs in developing countries: Case study of the Middle East and North African region. Energy Policy, 127(December 2018), 404-411. https://doi.org/10.1016/j.enpol.2018.12.023

Li, H., Goh, C., Hung, K., \& Chen, J.L. (2018). Relative Climate Index and Its Effect on Seasonal Tourism Demand. Journal of Travel Research, 57(2), 178-192. https://doi.org/10.1177/0047287516687409

Lior, N. (2017). Sustainable economic - environmental planning in Southeast Europe - beyond-GDP and climate change emphases. https://doi.org/10.1002/sd.1679

Liu, C., Susilo, Y.O., \& Karlström, A. (2017). Jointly modelling individual's daily activity-travel time use and mode share by a nested multivariate Tobit model system. Transportmetrica A: Transport Science, 13(6), 491-518. https://doi.org/10.1080/23249935.2017.1298682

Pennington, J.W., \& Thomsen, R.C. (2010). A semiotic model of destination representations applied to cultural and heritage tourism marketing. Scandinavian Journal of Hospitality and Tourism, 10(1), 33-53. https://doi.org/10.1080/15022250903561895

Roy, M., Yajing, F., \& Biswas, B. (2020). Economic contribution of tourism in Bangladesh. Tourism Marketing in Bangladesh, $223-237$. https://doi.org/10.4324/9781003007241-22

Sheldon, T.L. (2017). Asymmetric effects of the business cycle on carbon dioxide emissions. 61, 289-297. https://doi.org/10. 1016/j.eneco.2016.11.025

Siddig, K., Stepanyan, D., Wiebelt, M., Grethe, H., \& Zhu, T. (2020). Climate change and agriculture in the Sudan: Impact pathways beyond changes in mean rainfall and temperature. Ecological Economics, 169 (October 2019), 106566. https://doi.org/10.1016/j.ecolecon.2019.106566

Sroufe, R., \& Remani, V. G. (2018). Management, Social Sustainability, Reputation, and Financial Performance Relationships : An Empirical Examination of U.S. Firms. https://doi.org/10.1177/1086026618756611

Sun, H. ping, Tariq, G., Haris, M., \& Mohsin, M. (2019). Evaluating the environmental effects of economic openness: evidence from SAARC countries. Environmental Science and Pollution Research, 26(24), 24542-24551. https://doi.org/10.1007/s11356-019-05750-6

Taconet, N. (2020). Influence of climate change impacts and mitigation.

$\mathrm{Wu}, \mathrm{H}$. (2016). The impact of climate changes on mass events in China. 2857(March). https://doi.org/10.1080/10042857.2016.1138746

Zhang, X., Zhang, H., \& Yuan, J. (2019). Economic growth, energy consumption, and carbon emission nexus: fresh evidence from developing countries. Environmental Science and Pollution Research, 26(25), 26367-26380. https://doi.org/10.1007/s11356-019-05878-5

Article history: Received: 08.06.2021 Revised: 12.09.2021 Accepted: 08.10.2021 Available online: 01.11.2021 